Kelaniya Journal of Human Resource Management

Volume 11, Number 02 - July 2016

DOI: http://doi.org/10.4038/kjhrm.v11i2.30

\title{
Impact of Psychological Contract on Employee Outcomes of Job Satisfaction and Organizational Commitment: Evidence from a Leading Apparel Manufacturing Company in Sri Lanka
}

\author{
H. M. Nishanthi ${ }^{1}$ and W. G. S. Mahalekamge ${ }^{2}$ \\ ${ }^{1,2}$ Department of Human Resource Management, Faculty of Commerce and \\ Management Studies, University of Kelaniya, Sri Lanka \\ ${ }^{1}$ menakahewawaduge@gmail.com, 2.geethanimahalekmage@yahoo.com
}

\begin{abstract}
The purpose of this study is to examine the impact of psychological contract on employee outcomes of job satisfaction and organizational commitment in a leading apparel company. Companies that invest more effort in achieving higher level psychological contract between their employees, employer and organization have satisfied and committed employees. The research design is descriptive in nature. A simple random sampling has been used to select the sample. The participant in the study was 50 executive level employees in a leading apparel company in Sri Lanka. Standard questionnaire is distributed to collect data. Based on the analysis, researcher identified that there is a strong positive relationship between psychological contract and employee outcomes of job satisfaction and organizational commitment. As well as based on findings researchers established that there is a significant impact of psychological contract and employee outcomes of job satisfaction and organizational commitment.
\end{abstract}

Keywords: Job Satisfaction, Organizational Commitment, Psychological

Contract

\section{Introduction}

Psychological contact is a useful concept in today's work places. It used to understand employees' relationships with their employers (Turnley \& Feldman, 2000). The psychological contract is defined as the "implicit and explicit promises two parties' makes to one another" (Rousseau \& Tijoriwala, 1998). Good HR practices directly impacy to positive employee outcomes 
such as commitment to the company, trust in management, higher levels of cooperation, higher level of job satisfaction, higher levels of effort and involvement, and a lower inclination for employees to leave the company (Collins, Ericksen, \& Allen, 2005).

According to Kaliski (2007) job satisfaction further implies enthusiasm and happiness with one's work and it is the key ingredient that leads to recognition, income, promotion and achievement of other goals that lead to a feeling fulfillment.

According to Balfour and Wechsler (1996) employee commitment is defined as an employee's desire to remain with the organization (Saiyadain, 2003).

Effective ppsychological contract helps to improve the job satisfaction of employees. Many scholars have to investigate the psychological contract on job satisfaction during the last few decades. According to Ballou (2013), breaching psychological contract is adversely affect to job performance and job satisfaction of employees and their commitment. Yalabik (2014) has alos identifed that, there is an impact of psychological contract on employee outcome such as job satisfaction and employee commitment. Further it has been stated that, breaching psychological contract adversly effect on job performance, job satisfaction, employee commitment, etc. Therefore in today most of the organizations try to maintain good psychological contract between the organization and the employee.

Therefore, the current study is focused in identifying the impact of psychological contract on job satisfaction organizatiol commitment of the leading apparel company in Sri Lanka.

\section{Research Problem}

According to Turnley, Bolino, Lesterand and Bloodgood (2003), Psychological contract breach is negatively related to job satisfaction. CoyleShapiro (2002) stated that when the organization fulfills its promised obligations, employees may be motivated and engaged in discretionary behaviors, including increased effort and organizational citizenship. As per Robinson and Rousseau (1994), psychological contract violations affect to employees those who have high levels of trust or commitment to the company. Job satisfaction is a useful outcome in psychological contract due 
to its strong links with other attitudinal and behavioral outcomes such as commitment and job performance has been linked more strongly with contract fulfillment than obligation or breach (Lambert, Edwards \& Cable, 2003). Consequently identified problem is "What is the impact of psychological contract on employee outcomes of job satisfaction and organizational commitment?"

\section{Research Objectives}

General objective of this research is to examine the impact of psychological contract on employee outcomes of a leading apparel manufacturing company in Sri Lanka. On that general objective, specific objectives are established as follows.

1. To identify the impact of psychological contract on job satisfaction

2. To identify the impact of psychological contract on employee commitment

\section{Literature Review}

\subsection{Psychological Contract}

In recent years, the concept of psychological contract has achieved considerable prominence as it advances our understanding of employees' attitudes and behaviors in the contemporary time (Coyle -Shapiro \& Kessler, 2000). According to Aggarwal and Bhargava (2009), psychological contract refers to the relationship between employee and employer in terms of the unwritten expectations that exists (Rousseau, 1989). Further, Rousseau (1989) has identified that, Psychological Contract can be classified into four categories as transitional, transactional, balance and relational contracts. Transitional contract is a passing phase of relationship between the two parties reflecting the absence of commitment regarding further employment. Transactional psychological contract indicates obligations that may be considered to be "economic" in nature. Relational contracts involve long term obligations based upon trust and are concerned with personal, socioemotional as well as economic resources. Balance psychological contract 
refers, contain of both transactional and relational dimensions (Rousseau, 1989).

\subsection{Job Satisfaction}

Job satisfaction is an important attribute that organizations desire of their staff (Oshagbemi, 2003). However dissatisfied employees are prone absenteeism and excessive turnover (Chen, Yang, Shiau and Wang (2006) it is also noted that, job satisfaction improves work performance, productivity and enhance commitment. Rizwan, Khan, Tariq, Ghaffar (2012) has defined Job satisfaction as the feelings and thoughts of employees about their work or place of work. Bodur (2002) stated that there are some factors related to job satisfaction that is work substances, age, sex, educational level, psychological contract, work place environment etc. Brikend (2011) studied job satisfaction and found that job satisfaction is under the influence of series of factors such as the nature of work, salary, advancement opportunities, management, psychological contract, work group and work conditions.

\subsection{Organizational Commitment}

Meyer and Allen (1996) emphasized that organizational commitment reflects the psychological status between employees and organizations. It implies that the employee determinations of whether to stay or not stay in organization and it contains three dimensions: affective commitment which describes employees' willingness to stay in organization as their affection to organization. Normative commitment reflecting employee commitment to stay in organization as their sense of social responsibility and obligation and continuance commitment which reflect employee commitment to stay in organization based on utilitarian consideration. According to Meyers and Allen (1996), organizational commitment is the employees' psychological perception of the relationship between individuals and organizations and it reflects employee psychological status of been loyal to the organization.

\subsection{Effects of psychological contract on job satisfaction}

According to Armstrong (2006), Job satisfaction refers to the attitude and feelings people have about their work. Positive and favorable attitudes towards the job indicate job satisfaction and negative and unfavorable attitudes towards the job indicate job dissatisfaction. According to Hoppock (1935, as cited in Jam \& Fathima, 2006)), there is a strong relationship between worker's emotional adjustment (psychological contract) and levels 
of job satisfaction. Furthermore violation of the transactional obligations such as pay, benefits and promotions of the psychological contract result in decrease in job satisfaction (Anderson \& Schalk, 1998).

\subsection{Effects of psychological contract on organizational commitment}

Psychological contract reflects the beliefs system of employees to mutual responsibility and obligation between individuals and organizations. It involves bidirectional relationship which reflects employees' belief to taking responsibilities and the organization taking responsibilities (Casser \& Briner, 2011). According to the study conducted by Lou and Yo (2013), psychological contract has a significant impact on organizational commitment. Furthermore employees whom the organization should value the most were most affected by the psychological contract violation (Robinson \& Rousseau, 1994).

\section{Conceptual Framework}

In this study, psychological contract has been considered as the independent variable and the employee outcomes of job satisfaction and organizational commitment have been considered as the dependent variables.

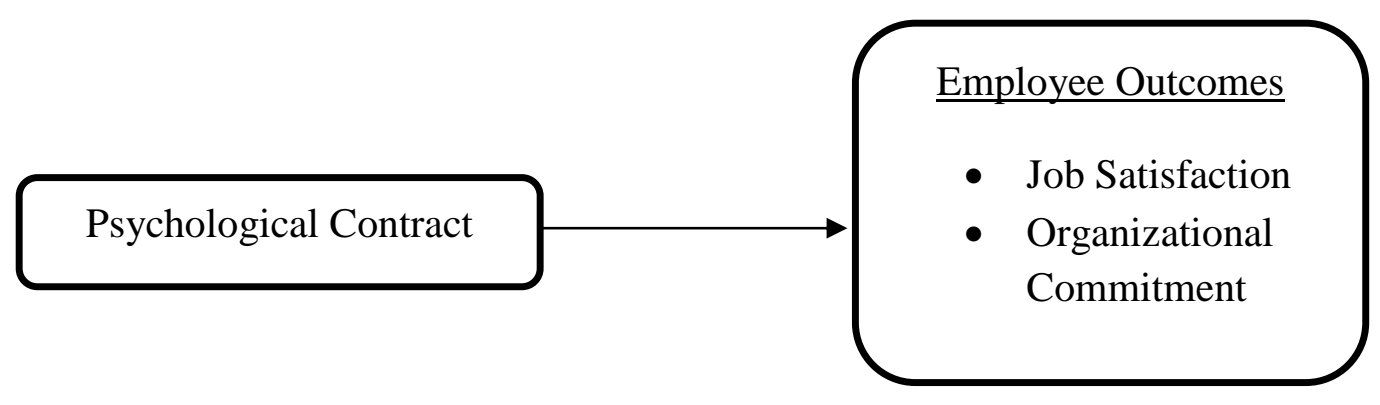

Figure 01: Conceptual Framework

Source: Authors 


\section{Hypotheses}

H1: There is a significant impact of psychological contract on Job Satisfaction

H2: There is significant impact of Psychological contract on Organizational Commitment

\section{Methodology}

\subsection{Sampling Method}

Simple random sampling method is the technique used by the researchers as sampling method to provide equal opportunities to the population of the sample. Here the sample consists of fifty (50) executive level employees in a leading apparel manufacturing company in Sri Lanka out of 70 employees (population). Sample has been collected from three departments of the company which include marketing, business development unit and merchandising which consists with four levels of employees such as, Merchandiser. Manager, Business development associate and Bank associate.

\subsection{Method of Data collection}

Primary and secondary data collection methods have been employed in the study. Primary data has been gathered by using a structured questionnaire while through internet, journal articles, text books \& publications, secondary data has been collected.The questionnaire consists 48 close ended questions. Researchers used standard questionnaires. The strength of psychological contract was measured by the questionnaire developed by Harold Andrew Patrick (Patrick, 2008).The instrument used to measure job satisfaction is the Job Satisfaction Survey designed by Paul E. Specter (Specter, 1994, as cited in Amburgey, 2005) Employee commitment was measured by the 10-item Employee commitment Questionnaire (OCQ) (Porter et al., 1974, as cited in Luthan, 1998). Five point Likert- scale was used to score the responses.

\subsection{Data Analysis}

Quantitative method was used to analyze data. The researchers used some statistical tools such as, mean, median, mode \& standard deviation, 
regression, Pearson correlation coefficient to analyse data and SPSS package version 20.

\section{Findings and Discussion}

\subsection{Sample Profile}

Table 1: Sample Description

\begin{tabular}{llrr}
\hline Factor & Majority & Frequency & Percentage \\
\hline Gender & Female & 26 & $52.0 \%$ \\
Age & $25-29$ & 21 & $42.0 \%$ \\
Education & Professional & 27 & $54.0 \%$ \\
Experience & $2-5$ years & 16 & $32.0 \%$ \\
Job position & Merchandiser & 22 & $44.0 \%$ \\
Department & Marketing & 30 & $40.0 \%$ \\
\hline
\end{tabular}

Source: Survey Data

In this sample majority respondents are female (52\%) in age the age category of 25-29 years. 54\% of the respondents have professional qualifications and $32 \%$ of the sample have 2-5 years working experience. $44 \%$ respondents held Merchandiser position and majority of the respondents (40\%) respondents are from the Marketing department.

\subsection{Reliability Statistics}

\section{Table 2: Reliability}

\begin{tabular}{lcc}
\hline Construct/Variable & Cronbach Alpha & No of Items \\
\hline Psychological Contract & .854 & 23 \\
\hline Job Satisfaction & .811 & 18 \\
\hline Organizational Commitment & .850 & 07 \\
\hline Overall Questionnaire & .934 & 48 \\
\hline
\end{tabular}

Source: Survey Data 
Overall reliability of the questionnaire is 0.9 (Cronbach Alpha Value).Hence, it could be noted that the data are reliable to study.

\subsection{Descriptive Statistics}

Table 3: Descriptive Statistics

\begin{tabular}{llll}
\hline Measure & $\begin{array}{c}\text { Strength of } \\
\text { Psychological } \\
\text { Contract }\end{array}$ & $\begin{array}{c}\text { Job } \\
\text { Satisfaction }\end{array}$ & $\begin{array}{c}\text { Organizational } \\
\text { Commitment }\end{array}$ \\
\hline Mean & 4.17 & 4.05 & 4.30 \\
\hline Median & 4.26 & 4.17 & 4.36 \\
\hline Mode & 3.91 & 4.17 & 4.00 \\
\hline SD & 0.35 & 0.37 & 0.47 \\
\hline Skewness & -0.56 & -0.91 & -0.48 \\
\hline Kurtosis & -0.38 & 1.58 & -0.48 \\
\hline
\end{tabular}

Source: Survey Data

The mean value of Psychological Contract is 4.17. Therefore the strength of psychological contract is "High". According to that the mean value of job satisfaction is 4.05 and Std. Deviation is 0.37 . Therefore the motivation employee job satisfaction is "High" and also the mean value of Organizational commitment is 4.3 and Std. Deviation is 0.4937. Therefore organizational commitment is "High" in this organization. The data of the present study shows that the statistical values of skewness and kurtosis are between +2 and -0.91 . According to Kline (2005) skewness and kurtosis are between +2 and -2 , the data is normally distributed on the 0.05 level. So, in this study the data has been distributed properly.

\subsection{Regression Analysis}

Following table 4 and 5 depicts the regression analysis of the study. 
Kelaniya Journal of Human Resource Management

Volume 11, Number 02 - July 2016

Table 4: Impact of Psychological Contract on Job Satisfaction

\begin{tabular}{lc}
\hline Variable & $\begin{array}{c}\text { Impact of Psychological Contract on Job } \\
\text { Satisfaction }\end{array}$ \\
\hline R Square & 0.734 \\
\hline Adjusted R Square & 0.729 \\
\hline F & 132.57 \\
\hline Significance & 0.000 \\
\hline B- Constant & 0.308 \\
\hline Standardize Beta & 0.857 \\
\hline
\end{tabular}

Source: Survey Data

According to table 4, $\mathrm{R}$ square which is the explained variance is 0.734 at a significant level of 0.0. This suggests that the influence of psychological contract on job satisfaction is significant. This result means that $73 \%$ variance ( $\mathrm{R}$ square) in job satisfaction is explained by the independent variable psychological contract. Therefore, $\mathrm{H} 1$ is accepted.

Table 5: Impact of psychological contract on Organizational Commitment

\begin{tabular}{lc}
\hline Variable & $\begin{array}{c}\text { Impact of Psychological Contract on } \\
\text { Organizational Commitment }\end{array}$ \\
\hline R Square & 0.872 \\
\hline Adjusted R Square & 0.869 \\
\hline F & 326.28 \\
\hline Significance & 0.000 \\
\hline B- Constant & 0.864 \\
\hline Standardize Beta & 0.934
\end{tabular}

Source: Survey Data

According to table 5, R square which is the explained variance is 0.872 at a significant level of 0.0. This suggests that the influence of psychological contract on organizational commitment is significant. This result means that $87 \%$ variance (R square) in organizational commitment is explained by the independent variable psychological contract. Therefore $\mathrm{H} 2$ is accepted. 


\subsection{Correlation Analysis}

Using the Pearson Correlation with two-tailed test of significance, the Correlation analysis was made to investigate the associations between psychological contract and employee outcome of job satisfaction and organizational commitment.

Table 6: Correlations among Variables

\begin{tabular}{|l|l|l|l|}
\hline & $\begin{array}{c}\text { Psychological } \\
\text { Contract }\end{array}$ & $\begin{array}{c}\text { Job } \\
\text { Satisfaction }\end{array}$ & $\begin{array}{c}\text { Organizational } \\
\text { Commitment }\end{array}$ \\
\hline Psychological Contract & 1 & $.857 * *$ & $.934 * *$ \\
\hline Job Satisfaction & $.857 * *$ & 1 & $.837 * *$ \\
\hline $\begin{array}{l}\text { Organizational } \\
\text { Commitment }\end{array}$ & $.934 * *$ & $.837 * *$ & 1 \\
\hline
\end{tabular}

Source: Survey Data

\section{Notes:}

** Correlation is significant at the 0.05 level (2-tailed)

According to the table it is noted that psychological contract is positively and strongly correlated $(\mathrm{r}=.857, \mathrm{p}<0.05)$ with job satisfaction. As well as there is positive and strong relationship between psychological contract and organizational commitment $(r=.934, \mathrm{p}<0.05)$.

\section{Conclusion}

The purpose of this research is to identify the impact of psychological contract on employee outcomes of job satisfaction and organizational commitment. To achieve that purpose the researcher selected executive level employees in one of a leading apparel manufacturing company in Sri Lanka. Because of time limitation and convince, this study is limit to executive level employees in only one branch of the leading appeal company. A wellstructured questionnaire was employed to gather data from a sample of fifty executive level employees. According to the regression analysis, there is a $76 \%$ impact of psychological contract on job satisfaction and $87 \%$ impact of psychological contract on organizational commitment. 
Further, according to the correlation analysis there is significant relationship between psychological contract and the employees' outcomes in the form of job satisfaction and organizational commitment and it has strong positive relationship. Hence, it could be concluded that having a better psychological contract between the employees and the organization enables to obtain positive employee outcomes in the form of job satisfaction and organizational commitment.

\section{References}

Aggarwa, U., \& Bhargava, S. (2009). Exploring psychological contract contents in India: the employee and employer perspective. Journal of indian business research, 1(4), 238-251.

Amburgey, W. D. (2005). an analysis of the relationship between job satisfaction, organizational culture and percieved leadership characteristics. Retrieved 07,07,2016,fromhttp://etd.fcla.edu/CF/CFE0000610/Amburgey_William_ OD_200508_EdD.pdf

Anderson, N., \& Schalk, R. (1998). The psychological contract in retrospect and prospect. Journal of organiztional behavior, 19, 637-647.

Armstrong, M. (2006). A handbook of human resource management practices $\left(10^{\text {th }}\right.$ ed.). London: Kogan page publishing.

Ballou, N. S. (2013). The Effects of Psychological Contract Breach on job outcome.

Brikend, A. (2011). Job satisfaction. Management research and practices, 3(4), pp. 77-86.

Chen, S. H., Yang, C. C., Shiau, J. Y., \& Wang, H. H. (2006). The development of an employee satisfaction model for higher education. The TQM Magazine, 18(5), pp. 484-500.

Collins, C. J., Ericksen, J., \& Allen, M. (2005). Employee outcomes:Human Resource Management practices and performance in small business. Retrieved 10 01, 2016, from http://digitalcommons.ilr.cornell.edu/cahr

Coyle-Shapiro, J. A. (2002). A psychological contract perspective on organizational citizenship behavior. journal of oragizational behavior, 23, 46-927.

Coyle-Shapiro, J. M., \& Kessler, I. (2000). Consequences of psychological contract for the employment relationship:a large scale survey. Journal of management studies, 37, 30-903.. 
Kelaniya Journal of Human Resource Management

Volume 11, Number 02 - July 2016

Jam, F. A., Haq, I. U., \& FatimaT. (2006). Psychological contract and job outcome: mediating role of affective commitment. Journal of management, 4(2), 1325.

Kaliski, B. S. (2007). Encyclopedia of business and finance (2nd ed.). Thompson Gale.

Kline, R. (2005). Principles and practice of structural equation modeling. New York: The Gilford press.

Lambert, L. S., Edwards, J. R., \& Cable, D. M. (2003). Breach and fulfilment of the psychological contract: a comparison of traditional and expanded views. Personal psychology, 56(4), 895-934.

Meyer, J. P., \& Allen, N. J. (1991). A three componenet conceptualization of organizational commitment. Human resource management review, 1, 6189.

Muhammad Rizwan, W. M. (2012). Empirical study of Employee job Satisfaction. IOSR journal of Business and Management, 29-35.

Oshagbemi, T. (2003). Personal correlates of job satisfaction: empirical evidence from UK Universities. International journal of social economics, 30(12), 32-1210.

Patrick, H. A. (2008). Psychological contract and employment relationship. Retrieved 07 15, 2016, from http://vodppl.upm.edu.my/uploads/docs/dce5634_1298965509.\%20contrac t\%20\&\%20employment\%20r.ship.pdf

Psychologicall contract. (n.d.). Retrieved 07 07, 2016, from Businessball.com: http://www.businessballs.com/psychological-contracts-theory.htm

Rizwan, M., Khan, W. M., Tariq, H. M., \& Ghaffar, A. (2012). Empiricala study of employee job staisfaction. Journal of business and management, 29-35.

Robinson, S. L., \& Rousseau, D. M. (1994). Violating the psychological contract:not the exception but the norm. Journal of organizational behavior, 15, 245-259.

Rousseau, D. M., \& Tijoriwala, S. A. (1998). Assessing psychological contract: Issues, alternatives and measures. Journal of Organizational Behavior, 19, 679-695.

Saiyandain, M. S. (2003). Human resource management (3rd ed.). Tata McGrow Hill publishing ltd. 
Kelaniya Journal of Human Resource Management

Volume 11, Number 02 - July 2016

Turnley, W. H., \& Feldman, D. C. (n.d.). Re- examining the effect of psychological cntract vioalation:Unmet expectations and job satisfaction as a mediators. Journal of Organizational Behavior, 21, 25-42.

Turnley, W. H., Bolino, M. C., \& Bloodgood, J. M. (n.d.). The impact of psychological contract fulfilment on the performance of in role and organizational citizenship behavior. Journal of management, 29(2), 187206.

Yalabik, B. A. (2014). Work engagement, psychological contract breach and job satisfaction. 